\title{
MEMAHAMI KEPUTUSAN MENINGGALKAN ZONA NYAMAN KARYAWAN "X" BUMN
}

\author{
Mirza Dwinanda Ilmawan ${ }^{1}$ \\ Program Studi Manajemen, Universitas Internasional Semen Indonesia, Gresik \\ Indonesia, mirza.ilmawan@uisi.ac.id \\ Feisal Ala'i \\ Program Studi Manajemen, Universitas Internasional Semen Indonesia, Gresik \\ Indonesia, feisalai26@gmail.com
}

\begin{abstract}
Background - Leadership and organizational culture is one of the keys for someone deciding to leave or maintain their work comfort zone. BUMN companies are taken in this case because of the social fact that these companies are able to provide adequate compensation and even tend to be abundant. However, whether these social facts are in line with the facts in the field will be the focus of this study to reveal these things that are juxtaposed with organizational culture and leadership in it.
\end{abstract}

Diterima : 27 November 2020

Direview : 24 Februari 2021

Direvisi : 03 Mei 2021

Disetujui : 18 Mei 2021

Purpose - This study aims to obtain an empirical picture in the field in order to find the justification for someone leaving the comfort zone of BUMN.

Design / Methodology / Approach - This research uses explanatory principles by digging up information related to the decision to leave the comfort zone of BUMN, an interesting phenomenon in which BUMN employees are known to receive better compensation than other companies and have secured prestigious positions in the company but choose to leave. The selected subjects are BUMN executive employees who choose to leave their positions before entering retirement.

Result and Discussion - The results of this study reveal an interesting fact where respect for company executives is a very important thing that must be given by the CEO/President Director and if there is any neglect of this, the risk faced is the loss of potential employees. Other findings may be that further study is the best option to reduce work stress.

Conclusion - Organizational culture factors that are too dynamic have a positive influence on leaving the comfort zone of work.

Researh Limitations - This study uses a limited subject, therefore the picture described follows the limitations of the number of subjects taken

Keywords : Compensation, Leadership, Conflict

\begin{abstract}
ABSTRAK
Latar Belakang - Kepemimpinan dan budaya organisasi menjadi salah satu kunci seseorang memutuskan untuk meninggalkan atau mempertahankan zona nyaman pekerjaannya. Perusahaan BUMN diambil dalam hal ini karena adanya fakta sosial perusahaan ini mampu memberikan kompoensasi dalam jumlah cukup bahkan cenderung berlimpah. Namun apakah fakta sosial ini sejalan dengan fakta dilapangan akan menjadi fokus dalam penelitian ini untuk mengungkap hal tersebut yang disandingkan dengan budaya organisasi dan kepemimpinan didalamnya.

Tujuan - Penelitian ini bertujuan untuk mendapatkan gambaran empiris dilapangan guna menemukan justifikasi seseorang meninggalkan zona nyaman BUMN.

Desain / Metodologi / Pendekatan - Penelitian ini menggunakan prinsip eksplanatory dengan menggali informasi terkait keputusan meninggalkan zona nyaman BUMN, fenomena menarik dimana karyawan BUMN dikenal menerima kompensasi yang lebih baik ketimbang perusahaan lain dan telah mancapat jabatan prestisius dalam perusahaan namun memilih pergi. Subyek yang dipilih merupakan karyawan eksekutif BUMN yang memilih untuk meninggalkan jabatan sebelum memasuki masa pensiun.
\end{abstract}


Hasil dan Pembahasan - Hasil dari penelitian ini mengungkapkan fakta menarik di mana penghargaan terhadap pejabat eksekutif perusahaan merupakan hal yang sangat penting yang harus diberikan oleh CEO/Direktur Utama dan apabila terdapat pengabaian akan hal ini, risiko yang dihadapi adalah kehilangan karyawan potensial. Temuan lain bisa jadi studi lanjut merupakan opsi terbaik untuk menekan stres kerja.

Kesimpulan - Faktor budaya organisasi yang terlalu dinamis menimbulkan pengaruh positif seseorang meninggalkan zona nyaman pekerjaan.

Batasan Penelitian - Penelitian ini menggunakan subjek yang terbatas, oleh karenanya gambaran yang dijabarkan mengikuti keterbatasan dari jumlah subjek yang diambil.

Kata Kunci : Kompensasi, Kepemimpinan, Konflik

\section{PENDAHULUAN}

BUMN atau Badan Usaha Milik Negara merupakan badan usaha dimana sebagian atau seluruh modal yang ada dalam perusahaan dimiliki oleh Negara melalui penyertaan langsung yang berasal dari kekayaan negara yang dipisahkan (UU Nomor 19 Tahun 2003 tentang BUMN, pasal 1). BUMN adalah suatu entitas yang beroprasi secara mandiri di jalur komersil. Perusahaan milik negara baik milik Indonesia, Malaysia, India dan lain sebagainya memiliki kontribusi besar dalam meningkatkan tingkat ekonomi negara tersebut. Kontribusi yang sangat besar tersebut hendaknya sangat penting bagi pemerintah untuk memastikan bahwa BUMN dapat melakukan kegiatan operasionalnya seefisien mungkin sehingga diharapkan dapat terus meningkatkan kinerjanya serta dapat terus mampu mendorong BUMN untuk terus memberikan kontribusinya dalam peningkatan ekonomi suatu bangsa. Sementara optimalisasi keuntungan untuk meningkatkan kesejahteraan dari para pemegang saham dipercaya menjadi tujuan perusahaan yang semestinya. Perusahaan milik negara semestinya tidak hanya mengejar laba semata namun diharapkan dapat terus menciptakan lapangan kerja baru, membantu ekonomi daerah tertinggal, meratakan pembangunan, melaksanakan kegiatan bisnis yang potensi, meningkatkan kemampuan teknologi nasional, menjadi penstabil harga bahan baku atau bahkan sebagai pendulang devisa negara.

Banyak kritik yang ditujukan terhadap perusahaan milik negara di seluruh dunia tak terkecuali BUMN di Indonesia. Banyak sekali argumen berpendapat bahwa kinerja perusahaan swasta masih kalah inferior apabila dibandingkan dengan perusahaan plat merah kita. Argumen ini didasarkan atas rasionalitas beban politis yang terlalu besar sehingga pucuk pimpinan diisi oleh orang yang terkadang tidak sesuai dengan kebutuhan baik dari segi kuantitas maupun kualitas atau dalam arti lain lebih memilih memperkerjakan personil yang lebih memiliki koneksi politis ketimbang personil yang memiliki kualifikasi yang sesuai 
dengan kebutuhan (Choi, 2019). Kritik lain bahwa BUMN memberikan kompensasi yang cukup tinggi bagi pekerjanya adalah sebagai salah satu alasan mengapa banyak aspek politis lebih kental di dalamnya.

Dalam durasi yang cukup singkat, antara tahun 2014-2018 BUMN "X" sampai 5 kali mengalami perubahan pucuk kepemimpinan. Tak pelak perubahan secara terus menerus dalam waktu cukup singkat tersebut menimbulkan polemik di dalam perusahaan. Aspek politis menjadi kambing hitam dalam hal tersebut. Meskipun gaji yang diterima oleh karyawan BUMN terbilang cukup tinggi karena tanggung jawab yang cukup besar namun beberapa karyawan dilaporkan mengundurkan diri dari perusahaan.

Perusahaan BUMN yang menjadi obyek dalam penelitian ini sebelumnya merupakan gabungan atau hasil dari merger dari beberapa perusahaan BUMN sejenis. Penggabungan ini bertujuan untuk peningkatan pangsa pasar dan kemampuan dalam meningkatkan keunggulan saing dari perusahaan tersebut di Indonesia. Bahkan perusahaan ini pun pada tahun 2014 berhasil mengakuisisi perusahaan asing sejenis. Pengembangan bisnis yang semakin meluas maka pangsa pasar pun makin meluas. Hal ini semestinya juga diikuti oleh peningkatan kompensasi yang diterima oleh karyawan mengikuti ukuran perusahaan. Meski kompensasi terbilang cukup tinggi, pada kenyataannya polemik pergantian kepemimpinan di tubuh BUMN ini tak mampu mempertahankan karyawan potensial dalam perusahaan baik jajaran low manajemen sampai top manajemen.

Dalam penelitian yang dilakukan oleh Nina dan Steven (2008) menyatakan bahwa ukuran perusahaan sangat menentukan besaran kompensasi yang diterima oleh CEO perusahaan. Merger yang dilakukan pada perusahaan BUMN tersebut maka semestinya pangsa pasar yang diraih pun juga semakin meluas. Namun penelitian tersebut bertolak belakang dengan temuan penelitian yang dilakukan oleh Winschel (2021) mengemukakan bahwa meskipun perusahaan mengadopsi hal baru dalam perusahaannya, pada kenyataannya kompensasi yang diterima jajaran CEO tidak mengalami banyak perubahan yang signifikan. Besaran kompensasi yang diterima dalam jangka pendek hanya mengacu pada target pasar yang diterima perusahaan.

Dari penjelasan di atas dapat disimpulkan bahwa pemberian kompensasi yang sejalan dengan berkembangnya ukuran perusahaan semestinya juga mampu memciptakan loyalitas terhadap jajaran manajemen yang berada dalam perusahaan plat merah BUMN tersebut. Dewasa ini salah satu isu penting yang memiliki kaitan erat dengan kompensasi adalah tentang loyalitas karyawan. Loyalitas 
menjadi salah satu syarat dan aturan tak tertulis bagi karyawan untuk terus mengabdi dan berkontribusi kepada perusahaan. Terlebih pada perusahaan BUMN dimana keuntungannya menjadi salah satu penopang pendapatan negara. Pada kenyataannya ada juga karyawan dari jajaran manajemen BUMN yang merasa bahwa tidak hanya kompensasi saja yang megikat mereka untuk bertahan di perusahaan. Penelitian dari Rishipal (2019) mengungkap bahwa faktor lain selain kompensasi adalah keamanan dan pertumbuhan kerja serta kepuasan terbukti bertanggung jawab atas kecenderungan loyalitas karyawan yang tinggi. Apabila hal tersebut tidak berjalan beriringan maka akan mengakibatkan keluarnya karyawan dari perusahaan.

Banyak perusahaan BUMN (Badan Usaha Milik Negara) yang dianggap sudah mampu memberikan fasilitas pemenuhan kebutuhan yang diinginkan oleh para tenaga kerja sesuai dengan teori hierarki kebutuhan Maslow. Sebagai perusahaan negara, gaji yang diberikan kepada para karyawan bisa dibilang cukup tinggi seiring beban kerja yang semakin besar yang diimbangi oleh berbagai fasilitas penunjang seperti jaminan kesehatan, kendaraan dinas hingga rumah dinas seharusnya sudah barang tentu wajib terpenuhi. Jika karyawan tersebut memberikan dampak positif yang besar bagi perusahaan melalui inovasi dan kontribusi yang diberikan, maka perusahaan memberikan penghargaan seperti publikasi pujian hingga kenaikan jabatan. Dengan beragamnya bentuk kompensasi yang diberikan oleh perusahaan, diharapkan secara langsung akan berdampak pada peningkatan kinerja dan kontribusi pada perusahaan. Secara fisik, karyawan akan merasa nyaman karena segala kebutuhan hidup dapat terpenuhi dan secara mental karyawan akan merasa aman secara finansial dan kesehatan keluarga mereka telah dijamin oleh perusahaan. Namun segala kompensasi yang diberikan pasti sebanding dengan beban kerja yang diterima. Tanggung jawab sebagai karyawan menuntut mereka untuk bekerja dengan mengedepankan profesionalitas.

Semakin meluasnya jaringan usaha bisnis perusahaan maka pastinya akan diiringi oleh banyaknya tugas yang harus diselesaikan. Hal tersebut seccara tidak langsung akan mempengaruhi dari fisik maupun mental karyawan sehingga rentan mengalami stres kerja. Selain itu tekanan kerja yang besar dari perusahaan bisa jadi mendorong konflik dalam diri pribadi maupun dengan lingkungan sekitar di tempat bekerja, beberapa karyawan memutuskan untuk resign dari BUMN meskipun gaji yang telah diberikan sangat mencukupi dan performa perusahaan menunjukkan angka positif. 
Tantangan untuk mempertimbangkan lingkungan tempat kerja sebagai lebih dari sekedar lingkungan fisik dapat ditelusuri kembali. Penelitian bertujuan untuk menetapkan bagaimana lingkungan kerja yang produktif dan memuaskan dapat dicapai. Dua studi Hawthorne utama adalah "Ilumination study" dan "Bank wiring room study". Hasil dari kedua studi ini menyoroti dampak lingkungan perilaku terhadap produktivitas (Roethlisberger dan Dickson, 1939). Namun, penulis seperti Becker (1990) telah mencoba untuk memperluas perdebatan dari hanya lingkungan fisik untuk memasukkan hubungan antara ruang, pola kerja dan budaya organisasi. Temuan lain menunjukkan bahwa menyediakan lingkungan kerja otonom tingkat tinggi tidak cukup untuk membuat karyawan menunjukkan perilaku mengarahkan diri sendiri jika kesenjangan persepsi antara pimpinan organisasi dengan karyawan tidak dikelola dengan baik (Choi, 2019). Menjadi sebuah pertanyaan menarik dengan pergantian kepemimpinan yang cukup intens di tubuh BUMN, apakah pemimpin memiliki cukup waktu bagaimana mensinergikan persepsi dengan karakteristik pribadi karyawan.

Kesejahteraan yang terjamin secara fisik saja belum bisa menjadi acuan seseorang karyawan akan selalu loyal pada perusahaan. Patut dicermati bahwa kemungkinan ada faktor selain kompensasi, lingkungan kerja, tekanan kerja dan banyak lagi yang menjadi pendorong bagi karyawan untuk meninggalkan zona nyaman sebagai seorang karyawan BUMN. Tujuan penelitian ini adalah untuk memahami dari sudut pandang karyawan terkait keputusan meninggalkan zona nyaman "X" BUMN.

\section{TINJAUAN PUSTAKA}

\section{Kompensasi}

Kompensasi menurut Zainal, et al (2014) adalah merupakan sesuatu yang diterima atas penggantian terkait kontribusi jasa yang telah diberikan karyawan kepada perusahaaan. Zainal, et al (2014) juga membedakan kompensasi ke dalam dua jenis yang berbeda yaitu kompensasi langsung dan kompensasi tidak langsung. Kompensasi langsung meliputi upah, gaji bonus atau komisi. Sedangkan kompensasi tidak langsung terdiri dari semua pembayaran di luar kompensasi financial seperti liburan, asuransi dalam berbagai hal, fasilitas dukungan anak pegawai atau kepedulian keagamaan dan sebagainya. Dalam kompensasi tak langsung juga terdapat berbagai tunjangan seperti tunjangan mendapatkan rumah dinas, tunjangan mobil dinas dan yang lainnya.

Kompensasi sebagai balas jasa dari perusahaan kepada karyawan yang harus dikelola karena kompensasi merupakan salah satu pengeluaran yang cukup besar bagi perusahaan. Pengelolaan kompensasi 
dalam perusahaan disebut manajemen kompensasi yang tujuanya untuk mengelola proses balas jasa yang dilakukan oleh perusahaan dan membantu tercapainya tujuan perusahaan. Hal tersebut sependapat dengan Zainal, et al (2014) yang secara umum menyatakan tujuan manajemen kompensasi adalah untuk membantu perusahaan mencapai tujuan keberhasilan strategi dan menjamin terwujudnya keadilan secara internal dan eksternal dari perusahaan.

\section{Kepuasan Kerja}

Kepuasan kerja dari karyawan dituntut untuk selalu dipertahankan oleh perusahaan dalam kaitannya mempertahankan karyawan untuk tetap bertahan dalam organisasi. Kepuasan kerja dalam hal ini merupakan keadaan emosional yang dirasakan oleh karyawan terkait pekerjaan yang diemban meliputi perasaan positif atau perasaan negatif. Robbins dan Timothy (2015) menyatakan kepuasan kerja merupakan suatu perasaan positif tentang pekerjaan yang dihasilkan sebagai evaluasi atas karakter pekerjaan yang dihadapinya. Sesorang yang memiliki tingkat kepuasan kerja tinggi, cenderung memiliki perasaan positif terkait pekerjaan yang dihadapinya, namun kepuasan level rendah yang dimiliki seseorang cenderung memiliki perasaan negatif terkait pekerjaannya. Sedangkan menurut Zainal, et al (2014) kepuasan kerja merupakan tingkat kepuasan dari tiap individu yang berbeda sejalan dengan nilai yang dianut dalam dirinya. Semakin tinggi penilaian terhadap pekerjaan yang dirasakan sesuai dengan kemauan atau keinginan individu, makin tinggi kepuasan terhadap pekerjaan.

Guna mengurangi risiko dari keputusan karyawan meninggalkan perusahaan maka perusahaan juga harus memperhatikan tekanan kerja yang diberikan kepada karyawan dimana menurut Zainal (2014) stres atau tekanan adalah suatu kondisi ketegangan yang terjadi menimbulkan ketidakseimbangan fisik dan psikis yang melibatkan kondisi emosi, proses berfikir dan kondisi seorang karyawan. Sedangkan menurut Robbins dan Timothy (2008) stres adalah keadaan dinamis dimana karyawan berhadapan dengan peluang atau sumber daya yang berkaitan dengan apa yang dihasratkan oleh karyawan tersebut sedangkan hasilnya dipandang tidak tentu namun penting. Pada intinya stres adalah suatu persepsi individu dimana seorang menganggap bahwa dirinya tidak mampu mengendalikan peluang atau ancaman yang dihadapinya sehingga berdampak pada kondisi fisik, mental dan juga emosional dari karyawan tersebut.

\section{Stress Kerja}

Stres kerja atau tekanan kerja adalah kumpulan dari berbagai hal seperti tekanan atas beban kerja, konflik internal, keletihan, ketegangan, panik, perasaan gelisah, anxieti 
dan hilang daya (Zainal, 2014). Hal ini merupakan penyumbang terbesar terkait stes yang memiliki akibat negatif bagi karyawan dari segi kesehatan fisik maupun psikologi karyawan. Stres kerja merupakan hal yang penting ditangani seiring gencarnya perusahaan untuk melakukan efisiensi kegiatan operasional perusahaan yang dimulai dari tingkat karyawannya untuk menghindari dampak yang ditimbulkan pada perusahaan baik secara langsung maupun secara tidak langsung untuk mempertahankan loyalitas karyawan.

Loyalitas merupakan suatu sikap dari individu melakukan berbagai hal untuk kebaikan apa yang dibelanya, meskipun terkadang apa yang dibelanya baik dalam hal yang disenagi maupun yang tidak disenangi. Menurut Hasibuan (2005) loyalitas karyawan meliputi berbagai bentuk peran serta dari karyawan dalam mengelola tenaga dan fikiran serta waktunya yang ditujukan untuk kepentingan organisasi. Merujuk dari pendapat itu loyalitas karyawan adalah suatu sikap dari karyawan yang dibutikan dari sikap setianya terhadap perusahaan saat perusahaan dalam kondisi apapun.

\section{Loyalitas Kerja}

Menurut Triansari (2005) dimensi loyalitas karyawan yang dititik beratkan pada pelaksanaan kerja antara lain pada aturan yang telah ditetapkan perusahaan, tanggung jawab terkait kewajiban dan hak kepada perusahaan, memiliki kapabilitas dalam bekerja sama, rasa memiliki organisasi, memiliki hubungan antar pribadi yang ada di organisasi, memiliki kesukaan terhadap pekerjaannya sehingga termotivasi dalam bekerja. Menurut Robbins dan Timothy (2015) motivasi adalah sebuah proses terkait kekuatan, arah dan kekuatan seseorang dalam menggapai sebuah tujuan. Sependapat dengan hal itu menurut Zainal (2014) motivasi merupakan kolaborasi dari sikap dan nilai yang menggerakkan individu untuk melaksanakan hal spesifik terkait tujuan individu. Dari kedua pendapat tersebut dapat ditarik kesimpuan bahwa motivasi merupakan upaya dari individu untuk mencapai tujuan yang ingin dicapainya.

\section{METODOLOGI PENELITIAN}

Obyek yang dipilih peneliti dalam penelitian ini yaitu salah satu BUMN yang sengaja kami sembunyikan identitasnya untuk menjaga privasi dari subyek penelitian. Metode kualitatif deskriptif dianggap tepat dalam penelitian ini mengingat tujuannya untuk memperoleh data yang lebih rinci atas sebuah fenomena yang terjadi di lapangan terkait alasan meninggalkan zona nyaman sebagai karyawan BUMN.

Adapun semua itu dapat dilihat melalui observasi lebih mendalam melalui proses 
wawancara terhadap informan untuk menyelidiki fenomena-fenomena tentang aspek perilaku, pendapat dan keinginan maupun kebutuhan individu ataupun kelompok yang terkait dengan penelitian. Alasan penelitian ini menggunakan jenis penelitian kualitatif deskriptif, karena sesuai dengan tujuan penelitian ini, di mana peneliti ingin output yang dihasilkan bukan menguji hipotesis akan tetapi berusaha untuk memahami pengambilan keputusan dari karyawan untuk meninggalkan zona nyaman sebagai karyawan BUMN

Informan utama pada penelitian ini merupakan karyawan BUMN yang memutuskan mengundurkan diri sebelum masa pensiun yang ditetapkan dengan metode purposive atau penetapan informan dilakukan secara sengaja oleh peneliti. Alasan penggunaan purposive agar data atau informasi yang diperoleh dari informan akurat dan dapat dipertanggungjawabkan secara ilmiah, karena metode purposive didasarkan pada pertimbangan tertentu yang mana informan dianggap paling tahu mengenai lingkup penelitian sehingga memudahkan peneliti dalam menjelajahi obyek penelitian (Sugiyono, 2012). Informan dalam penelitian ini memiliki jabatan terakhir di salah satu BUMN sebagai General Manager ICT. Adapun informan lain seperti Kepala Bagian SDM sebagai konfirmator dalam pengambilan data.

\section{HASIL DAN PEMBAHASAN}

Memiliki latar pendidikan yang berbeda dengan pekerjaan yang dihadapi di dunia kerja merupakan cerita yang sering kita dengar. Sebagai contoh, lulusan teknik elektro bekerja sebagai komedian kelas nasional (sebut saja Cak Lontong). Bahkan latar pendidikan yang dianggap rendah pun belum tentu menentukan kesuksesan seseorang dalam bekerja. Sebagai salah satu contoh adalah Bob Sadino yang menjadi salah satu pengusaha sukses di Indonesia dan berbagai macam cerita menarik di luar sana. Namun di sini kita tidak akan membahas tentang kisah lucu Cak Lontong membawakan lawakannya di depan publik maupun kisah nyentrik dari Bob Sadino, tetapi bagaimana cerita sukses ini juga berlaku juga pada General Manager salah satu perusahaan BUMN ternama di Indonesia.

Demi menjaga privasi dan keamanan beliau maka nama beliau kami samarkan. Beliau merupakan mantan General Manager ICT di salah satu BUMN ternama. Uniknya beliau merupakan alumnus sosial ekonomi pertanian di salah satu universitas di Jawa Timur namun di masa beliau bekerja, beliau justru mampu menduduki posisi strategis di bidang teknologi informasi yang mana hal ini tidak berkaitan sama sekali dengan ilmu akademis yang beliau dapatkan saat kuliah. Beliau lulus sarjana pada tahun 1991, dengan predikat sebagai 
lulusan terbaik, termuda dan tercepat di jurusanya. Beliau memilih jurusan sosial ekonomi pertanian karena kepedulian beliau terhadap sosial ekonomi masyarakat sekitar.

Menjadi pertanyaan menarik kenapa beliau yang notabene mengambil jurusan sosial ekonomi pertanian namun mampu menjadi orang yang sangat diperhitungkan di bidang teknologi informasi di tingkat perusahaan. Pada saat masa kuliah, beliau pertama kali berkenalan dengan dunia teknologi informasi adalah melalui orang tua (bapak) beliau sendiri. Kebetulan pada saat itu bapak dari beliau menjabat sebagai direktur dari anak usaha yang sampai dengan saat ini tetap menjadi anak usaha dari perusahaan BUMN dimana beliau pernah mengabdi. Ketika di bangku perkuliahan, beliau sering kali diajarkan oleh orang tua beliau tentang teknologi infomasi yang terkait dengan pekerjaan orang tua beliau. Kebetulan pekerjaan yang sering kali ditangani oleh orang tua beliau berkaitan dengan laporan keuangan, sehingga memaksa beliau untuk belajar dan memahami lebih dalam mengenai laporan keuangan. Namun banyak sekali kendala saat melaporkan laporan keuangan secara sistematis. Masih banyaknya prosedur yang dilakukan secara manual untuk melakukan kegiatan pelaporan membuat beliau dan orang tua beliau berpikiran untuk membuat inovasi berupa pembuatan skema pelaporan keuangan secara sistematis menggunakan teknologi informasi.

Meskipun beliau kuliah di jurusan sosial ekonomi, tidak menghambat beliau untuk belajar lebih dalam mengenai teknologi informasi. Hal tersebut juga didukung oleh salah satu dosen beliau yang memiliki kompetensi di bidang teknologi informasi. Dosen tersebut merupakan kepala pusat komputer di universitas. Beliau sering kali diajak untuk masuk dalam pusat komputer di universitas. Saking sering seringnya beliau berada di pusat komputer tersebut akhirnya beliau dipekerjakan di tempat tersebut. Beliau mendapatkan gaji dan beliau menggunakan gaji tersebut untuk membayar kuliah sendiri.

Tidak hanya itu, semasa kuliah beliau juga bekerja paruh waktu di lembaga kursus komputer yang ada untuk mengajarkan ilmu tentang komputer mulai dari tingkat SMA hingga tingkat lembaga pemerintahan. Kebiasaan ini semakin mengasah kemampuan beliau di bidang teknologi informasi. Kemahiran beliau di bidang teknologi informasi terdengar sampai ke penjuru kota, sehingga beliau sering kali diundang untuk menjadi pembicara di acara seminar tentang teknologi infomasi. Satu hal yang sangat mengagumkan dari beliau adalah pada saat masih duduk di bangku perkuliahan, beliau sudah dipercaya oleh salah satu anak usaha 
BUMN dimana orang tua beliau bekerja di sana untuk membuat program keuangan yang dibutuhkan oleh perusahaan tersebut.

Pada tahun 1991 beliau menyelesaikan masa kuliah. Selepas itu beliau menjadi tenaga freelance di bidang teknologi informasi di berbagai perusahaan swasta dan melanjutkan menjadi tenaga pengajar di lembaga-lembaga kursus komputer. Sampai akhirnya pada tahun 1993 beliau memutuskan untuk mengirimkan lamaran ke salah satu perusahaan BUMN. Beliau hanya mengirimkan lamaran ke BUMN tersebut tanpa mengirimkan lamaran ke perusahaan yang lain karena beliau memiliki cita-cita untuk mengabdikan diri pada induk perusahaan dimana orang tua beliau bekerja. Selain beliau sudah mengenal seluk beluk perusahaan tersebut dari orang tua, beliau juga berkeinginan memajukan perusahaan dimana beliau tumbuh berkembang dari dari perusahaan tersebut. Tidak butuh waktu lama beliau menanti balasan dari surat lamaran yang telah diajukan. Tahun itu juga beliau dipanggil untuk mengikuti serangkaian tes seleksi masuk perusahaan. Meskipun beliau merupakan anak dari salah satu pegawai perusahaan tersebut, beliau tetap diharuskan melalui serangkaian tahapan seleksi. Lamaran beliau ditujukan untuk mengisi lowongan sebagai staf Kelestarian Lingkungan Hidup (KLH). Hari pertama tes berjalan dengan baik sampai seluruh tahapan seleksi berakhir. Pada saat mendekati penempatan kerja, pihak personalia meninjau ulang curricullum vitae beliau dan nampaknya pihak personalia merasa penasaran terhadap berkas yang dilampirkan oleh beliau. Pihak personalia mendapati banyaknya ketidaksesuaian antara jurusan yang telah ditempuh dengan berkas-berkas yang dilampirkan. Maka dari itu beliau diminta untuk membuktikan dihadapan personalia mengenai kemampuan beliau di bidang teknologi informasi dan dipantau langsung oleh Kepala Departemen Information Technology (IT) pada saat itu.

Tes seleksi pun diadakan kembali secara khusus dengan metode yang berbeda dibanding yang lain. Beliau diminta untuk melakukan praktek seputar teknologi informasi mulai dari perakitan komputer dari nol sampai komputer tersebut dapat digunakan untuk menciptakan sebuah program khusus yang sengaja diminta oleh Kepala Departemen IT kepada beliau. Tes tersebut berjalan dan mampu diselesaikan oleh beliau mulai dari jam tujuh pagi hingga adzan maghrib berkumandang.

Pada akhirnya beliau tidak diterima sebagai staf KLH namun dari hasil tes kedua yang dilakukan secara khusus maka diputuskan personalia untuk menempatkan beliau sebagai Kepala Regu IT dengan status sebagai capeg dalam masa pelatihan bagian statistik \& komputerisasi. Sebenarnya 
jabatan Kepala Regu diperuntukkan untuk lulusan Diploma. Beliau di tempatkan sebagai Kepala Regu untuk sementara sembari menunggu kekosongan jabatan pada tingkatan Kepala Seksi yang memang diperuntukkan untuk lulusan sarjana. Menurut "S", hal tersebut terpaksa dilakukan oleh bagian kepegawaian mengingat mencari lulusan yang mampu dan ahli di bidang teknologi informasi sangat sulit sekali ditemukan pada saat itu. Di awal masa kerja beliau, beliau ditugaskan untuk menggarap sistem informasi rumah sakit milik perusahaan yang baru didirikan. Bahkan hingga tulisan ini dirilis, rumah sakit tersebut masih menggunakan fondasi sistem informasi yang dikerjakan oleh beliau dan hanya sedikit perubahan yaitu pengalihan bahasa ke bahasa yang lebih terkini.

Meskipun beliau bukan dari latar belakang pendidikan IT, tak lama bagi beliau untuk mendapatkan promosi jabatan. Promosi jabatan menurut Zainal et, al (2014) merujuk pada seorang karyawan yang dipindahkan dari suatu pekerjaan ke pekerjaan lain yang lebih tinggi terkain tanggung jawab, tugas dan posisi dengan diiringi oleh peningkatan dalam pembayaran yang dikeluarkan oleh perusahaan kepada karyawan. Dua tahun kemudian perusahaan mengadakan promosi jabatan di bagian IT yang pada akhirnya beliaupun turut juga dalam kebijakan promosi tersebut untuk menjabat posisi Kepala Seksi. Baru menjabat sebagai Kepala Seksi, beliau diberi amanat untuk membangun dan memelihara infrastruktur yang ada.

Menurut "S" sebagai Kepala Bagian SDM saat itu menilai kapabilitas dan inovasi informan utama saat menjabat sebagai Kepala Seksi adalah kemampuan menghubungkan sistem informasi menggunakan jaringan radio, yang pada saat itu sangat terbatas, ke seluruh pabrik yang ada di Indonesia. Saat itu menghubungkan sistem informasi masih belum menggunakan teknologi yang tergolong canggih seperti saat ini yaitu teknologi fiber optic. Tantangan yang beliau hadapi saat itu adalah bagaimana teknologi sistem radio (sebelum teknologi fiber optic muncul) masih dioperasikan secara manual. Apabila ada kendala maka beliau dan tim harus sigap dalam menangani masalah tersebut. Hal tersebut secara pribadi disadari oleh informan dan tim untuk stand by selama 24 jam. Tekanan kerja atau stres kerja seperti ini hampir dirasakan setiap hari bahkan sampai informan memutuskan untuk pensiun dini dari perusahaan.

Di akhir masa jabatan sebagai Kepala Seksi selama tujuh tahun ke belakang, membuat informan merasa bosan terhadap pekerjaan beliau. Rasa bosan tersebut timbul salah satunya karena semua level 
Kepala Seksi IT telah beliau jalani, berpindah dari satu divisi ke divisi yang lain di departemen yang sama. Pada akhirnya untuk menghilangkan rasa jenuh tersebut, beliau berinisiatif untuk mengambil atau mencari beasiswa untuk kuliah master di luar negeri. Meskipun jurusan yang diambil masih terkait dengan teknologi informasi, konsentrasi yang diambil agak sedikit berbeda dari latar belakang pekerjaan beliau sehari-hari sebgai Kepala Seksi teknologi informasi. Beliau mengambil konsentrasi di bidang e-Commerce/EBusiness stream dengan harapan beliau ketika kembali bekerja dapat ditempatkan di luar bidang IT misalnya ditempatkan di bagian pemasaran perusahaan.

Rotasi pekerjaan yang dianggap monoton tidak cukup membuat informan puas terhadap pekerjaannya, ditambah lagi dengan tuntutan pekerjaan yang relatif berat di perusahaan pemerintah ini. Menurut Zainal et, al (2014) bahwa salah satu indikator kepuasan kerja dapat dilihat bagaimana seorang karyawan menghadapi pekerjaannya. Apabila pekerjaan tidak mampu memberikan tantangan kepuasan yang cukup bagi karyawan maka karyawan akan bersikap biasa-biasa saja terhadap pekerjaannya atau bisa dianggap karyawan cenderung tidak menampilkan kinerja yang memadai. Di lapangan terungkap bahwa karyawan yang bekerja di bidang IT akan sulit berpindah atau dirotasi ke bagian lain di luar bidang IT. Alasanya karena ilmu yang dimiliki oleh bagian IT tergolong khusus. Sesuai dengan teori prinsip Peter yang dikemukakan Zainal et al., (2014) menjelaskan bahwa secara hierarki manusia memiliki kecenderungan untuk secara konsisten meningkatkan tingkat kompetensinya. Prinsip ini memiliki arti bahwa kinerja seseorang pada bidang tertentu belum tentu berlaku sama terkait hasil pada bidang pekerjaan lainya. Seperti contoh, bisa saja karyawan IT berpindah ke bagian lain, semisal bagian personalia ataupun pemasaran dan lain sebagainya, namun tidak semua karyawan di luar sana mampu untuk mengerjakan tanggung jawab dari bagian IT. Tuntutan pekerjaan yang dianggap berat ini cukup untuk membuat beliau bosan dan tingkat stres menjadi meningkat. Stres kerja merupakan kumpulan dari berbagai hal seperti yang diungkapkan oleh Zainal, et al. (2014) yang menyebutkan bahwa stres merupakan istilah yang mencakup tekanan, beban kerja, konflik internal maupun eksternal, keletihan akibat pekerjaan, ketegangan menghadapi pekerjaan, kepanikan, perasaan gelisah, anxieti dan hilang daya.

Menurut "S" awal mulanya, pihak kepegawaian merasa keberatan untuk mengizinkan beliau lanjut studi. Kepegawaian sebelumnya telah memiliki kebijakan tersendiri terkait studi lanjut. Karyawan yang ingin melanjutkan studi 
tidak diperkenankan mengambil studi yang berpotensi mengganggu rutinitas pekerjaan sehari-hari, apalagi sampai perusahaan mengeluarkan biaya untuk studi lanjut. Hal ini terkesan bagi beliau sebagai bentuk penolakan terhadap studi lanjut beliau. Padahal beliau sudah mendapatkan beasiswa penuh untuk melanjukan studi di luar negeri dimana beliau tidak akan membebani perusahaan. Rasa gelisah beliau pun terdengar sampai ke telinga direksi. Pada akhirnya justru direksi merasa bangga atas prestasi beliau, dimana beliau mampu mendapatkan beasiswa tersebut dan meminta bagian personalia untuk mengizinkan beliau lanjut studi. Kemudian direksi pun meminta kepada bagian personalia guna membuat kebijakan baru demi memacu karyawan lain untuk studi lanjut. Setelah kasus ini mencuat ke level direksi, bagian personalia baru menyadari pentingnya mengembangkan karyawan melalui studi lanjut. Setelah beliau berangkat untuk studi lanjut, akhirnya pihak personalia pun menggenjot para karyawanya untuk turut serta dalam melanjutkan studi. Perusahaan akhirnya memberikan alokasi anggaran untuk studi lanjut bagi karyawan yang terpilih. Saat beliau kuliah master, beliau mendapatkan sertifikasi profesional tingkat internasional seperti CISCO CCNA dan Program Client/ServerTier with ASP/ Web Server, ternet \& MSSQL Server 7.0.
Tak lama berselang setelah beliau menyelesaikan studi master di luar negeri dan kembali ke Indonesia, beliau diangkat menjadi staf bagian IT. Agak sedikit mengecewakan bagi beliau karena harapan sebelum beliau kuliah adalah dipindahkan ke bagian di luar IT. Kebijakan yang dilakukan oleh personalia ini mau tidak mau harus diterima dengan lapang dada. Meski dalam kondisi sedikit dikecewakan oleh kebijakan personalia, namun beliau tetap memiliki dedikasi yang tinggi dalam bekerja. Terbukti beliau mampu membawa nilai IT maturity level menjadi 4.14 dari skala 5, dimana menteri BUMN saat itu mensyarakat IT maturity level sebuah BUMN minimal berada di poin 3 .

Prestasi beliau yang begitu gemilang sebagai Kepala Bagian, maka beliau semakin mantap dipercaya untuk memegang posisi prestisius di perusahaan dan pada tahun 2016 beliau dipercaya untuk menduduki posisi sebagai General Manager ICT. Sebenarnya kenaikan jabatan ini sudah lama bisa didapatkan oleh beliau, namun karena kondisi Departemen ICT yang tidak sefleksibel departemen lain, maka mengakibatkan orang-orang yang bekerja di Departemen ICT sulit untuk mendapatkan promosi jabatan. Beliau pun baru bisa mendapatkan promosi jabatan sebagai General Manager (GM) setelah menunggu pejabat sebelumnya pensiun. 
Pada awal saat menjadi GM, beliau langsung diminta oleh Direktur Utama dari perusahaan tersebut untuk membuat sistem informasi yang terintegrasi ke semua jaringan pabrik yang ada di seluruh Indonesia dan perusahaan yang baru saja diakuisisi di luar negeri. Sistem informasi tersebut harus mampu diterjemahkan dengan mudah oleh pimpinan yang ada di perusahaan dan data yang disuguhkan valid terhadap kondisi nyata di lapangan. Sehingga proses efisiensi optimal pun dimulai dimana karyawan tidak bisa memanipulasi data secara manual.

Sebagai contoh bagian produksi yang sebelumnya dianggap sering memanipulasi data tentang jumlah produksi saat itu tidak mampu berkutik karena sistem informasi yang dirancang secara valid menyuguhkan data terkini di lapangan secara langsung. Tidak berhenti sampai disitu, beliau dan tim mampu menyelesaikan 39 project operation hanya dalam waktu satu tahun. Hal ini bisa dianggap sebagai proyek "GILA" bagi sebagian besar divisi IT di perusahaan lain bahkan perusahaan kelas multinasional sekalipun. Meskipun dengan kesibukan yang ada, beliau juga sering menyempatkan waktu untuk mengisi seminar-seminar tentang teknologi informasi di banyak universitas dan perusahaan yang lain.

Saat beliau sedang dalam masa kejayaan dimana beliau mampu menggenjot prestasi dan produktifitas dari anak buah yang juga didukung penuh oleh direktur utama pada saat itu, perusahaan mengalami kesedihan yang luar biasa karena pada saat itu juga secara mendadak harus ditinggalkan oleh direktur utama tersebut. Hari berganti hari, masa berganti masa, jabatan direktur utama secara singkat sering kali berganti. Tidak sampai masa tugas selesai satu periode, posisi ini harus digantikan oleh orang yang berbeda.

Pergantian ini membawa dampak yang luar biasa baik dari segi kebijakan maupun arah tujuan organisasi. Hal ini pun juga dirasakan oleh "S" yang pada periode ini menjabat sebagai Kepala Bagian Pengembangan Sumber Daya Manusia di perusahaan tersebut. Beliau merasakan banyak kebijakan yang seringkali diubah seiring pergantian kepemimpinan. Aspek politik sangat kuat dirasakan. Silih berganti pemangku jabatan semakin membuat ketidakpastian stabilitas perusahaan.

Perusahaan dalam menentukan kandidat direktur utama adalah diambil dari kandidat internal perusahaan. Isu-isu politik nyaring terdengar membawa dampak luar biasa bagi perubahan formasi di jajaran top manajemen. Pejabat dari luar perusahaan silih berganti mengisi formasi tersebut. Kurangnya pemahaman, pengalaman dan kompetensi di bidang industri dimana perusahaan ini berjalan banyak berpengaruh terhadap pola pikir dan budaya yang ada dalam perusahaan. 
Sang pengambil kebijakan di jajaran lebih tinggi dari top manajemen mungkin lupa tentang hal ini. Pejabat yang dipilih merupakan pejabat dari latar belakang perusahaan yang justru berasal dari grade yang lebih rendah dari pada perusahaan ini. Keangkuhan banyak dirasakan oleh sebagaian besar karyawan. Hal ini dapat terlihat dari penolakan karyawan yang melakukan aksi demonstrasi, dimana hal ini jarang sekali terjadi pada kepemimpinan sebelumnya. Aksi demonstrasi ini tidak direspon oleh pengambil kebijakan di jajaran setingkat di atas top manajemen. Banyak kebijakan yang dianggap berseberangan dengan visi dari perusahaan.

Budaya organisasi yang dipertahankan selama ini pun juga agaknya tidak sesuai dengan apa yang diterapkan oleh jajaran top manajemen. Pergolakan terjadi dimanamana dan dilakukan secara bergantian diberbagai anak perusahaan namun lagilagi hal ini tidak direspon dengan baik oleh top manajemen. Menurut "S" sebagai Kepala Bagian SDM, menyatakan banyak karyawan yang menganggap saat dimana sebelum seringnya pergantian kepemimpinan ini terjadi, sistem perusahaan sudah mengarah ke keadaan yang stabil.

Saat menuju ke arah keadaan yang stabil tadi, tidak didukung oleh top manajemen. Top manajemen saat ini memiliki visi dan misi yang jauh berbeda dari perusahaan. Top manajemen saat ini dinilai ingin menunjukkan jati diri dengan cara yang berbeda. Meraka ingin menunjukkan bahwa mereka mampu. Banyak karyawan merasakan keangkuhan dari rezim ini. Sistem-sistem yang ada banyak diubah dari apa yang biasa dijalankan oleh perusahaan, ke arah kebiasaan dimana top manajemen membawa kebiasaan-kebiasaan dari perusahaan sebelumnya. Bahkan bukan hanya sistem namun budaya yang dibawa oleh top manajemen saat ini dianggap tidak cocok dengan penerapan budaya yang ada di perusahaan saat ini.

Salah satu kebiasaan "nyeleneh" yang dibawa oleh top manajemen saat ini adalah lebih senang menggunakan konsultan dari pada menggunakan tenaga kerja yang tersedia di perusahaan. Padahal perusahaan sendiri telah memiliki banyak anak usaha konsultan yang biasa digunakan untuk mensukseskan tujuan organisasi sebelumnya. Konsultan saat ini merupakan rekanan top manajemen pada saat memimpin perusahaan sebelumnya. Pekerjaan-pekerjaan yang ditangani bukan merupakan pekerjaan yang urgent dan sebenarnya bisa ditangani oleh tenaga kerja dari dalam perusahaan.

Perusahaan ini menurut narasumber sangat jarang sekali menggunakan tenaga eksternal selama pekerjaan tersebut mampu ditangani oleh tenaga internal perusahaan. Namun pada kenyataanya saat 
ini pekerjaan sepele pun sebisa mungkin memanggil konsultan untuk menanganinya dan barang tentu konsultan tersebut merupakan rekanan dari top manajemen saat ini. Hal ini mengakibatkan luka yang mendalam di hati banyak pegawai termasuk narasumber kami. Prestasi gemilang yang telah dicapai beliau (narasumber), beliau tersinggung karena merasa disepelekan oleh top manajemen. Penghargaan yang diterima beliau sebelumnya tidak pernah diterima lagi saat ini, baik penghargaan atas prestasi maupun penghargaan atas gagasan. Top manajemen merasa lebih baik memanggil konsultan dari pada mempercayakan tanggung jawab kepada beliau.

Teori Maslow menjelaskan bahwa lima hirarki motivasi kerja seseorang terbagi atas kebutuhan fisiologis (sandang, pangan, papan), kebutuhan akan rasa aman (aman dari pekerjaan meliputi kepastian kerja, asuransi dsb), kebutuhan akan kepemilikan sosial (dimana perasaan diakui oleh lingkungan sekitar), kebutuhan akan penghargaan dan kebutuhan akan aktualisasi diri. Dari teori tersebut, kebutuhan fisiologis, rasa aman dan rasa kepemilikan sosial sudah dipenuhi oleh perusahaan. Namun, penghargaan akan prestasi dan gagasan beliau tidak diperhatikan dengan baik. Hal ini bertolak belakang dari penghargaan yang diberikan oleh kepemimpinan sebelumnya.
Selama 25 tahun berada dibagian ICT tanpa dipindahkan ke bagian lain, sudah pasti membuat beliau jengah, ditambah lagi dengan keadaan kepemimpinan saat ini yang tidak bisa dipahami. Sesuai dengan teori yang dikemukakan Hadi (1995) akibat pengkhususan terhadap suatu pekerjaan akan menimbulkan rasa bosan dan keinginan untuk meninggalkan pekerjaan. Beliau mulai merasakan ketidakcocokkan ini adalah ketika beliau membandingkan dimana pemimpin sebelumnya ketika ada suatu masalah terjadi, mereka memberikan solusi atas masalah tersebut. Namun, kepemimpinan saat ini cenderung arogan, dimana tidak ada solusi yang terucap dari meraka, hanya gebrakan meja yang sering terdengar oleh karyawan apabila terjadi masalah yang tidak mudah diselesaikan. Hal ini berbeda dengan kepemimpinan sebelumnya dimana dalam menhyelesaikan masalah selalu menggunakan kepala dingin dengan pemaparan solusi yang konkrit dan mudah dipahami oleh karyawan.

Beliau menambahkan jajaran direksi terbaik adalah pejabat saat perusahaan diterpa krisis pada tahun 1998, di mana dalam keadaan perusahahan hampir kolaps namun beliau bisa mempertahankan pegawainya untuk bertahan di perusahaan. Beliau turun tangan langsung guna memberikan kepercayaan kepada istri-istri pegawai bahwa perusahaan akan bangkit kembali. 
Permintaan beliau kepada istri-istri pegawai adalah untuk tidak memberikan beban materiil maupun psikis kepada suami sehingga mereka bisa bekerja tanpa beban dengan fokus untuk mengembalikan keadaan perusahaan. Kepercayaan dari istri pegawai tersebut dibayar lunas oleh direksi tersebut bahkan kondisi perusahaan jauh melampaui target yang diinginkan sehingga kondisi keuangan perusahaan maupun karyawan sangat di luar dugaan atau jauh melampaui ekspektasi banyak orang. Keadaan ini membuat kenangan yang tak terlupakan bagi segenap karyawan yang loyal terhadap perusahaan.

Narasumber akhirnya memilih meninggalkan perusahaan setelah bertahan dalam kekecewaan yang dirasakan. Hal lain yang mendukung keputusan ini adalah nama beliau yang telah dikenal di luar perusahaan. Banyak perusahaan lain yang menawarkan proyek untuk beliau. Perusahaan-perusahaan tersebut sangat senang bekerjasama karena prestasi beliau yang mampu mengangkat nama perusahaan lama beliau dalam hal perkembangan IT. Bahkan selain perusahaan, perguruan tinggi dengan reputasi mentereng pun banyak yang juga menginginkan jasa beliau sebagai tenaga pengajar. Beliau mengatakan bahwa:

"Mungkin karena umur saya sudah tua, tidak memungkinkan saya jadi dosen tetap Universitas"
Saat ini beliau menjadi salah satu dosen lepas di berbagai universitas mentereng dan juga membantu berbagai perusahaan sebagai konsultan guna memperbaiki sistem informasi perusahaan, utamanya dalam menghadapi era industrialisasi 4.0 saat ini. Hal ini menjadi nilai positif beliau karena ilmu yang diajarkan langsung dari dunia kerja atau pun dunia industri dan berbagai masalah yang dihadapi berbagai perusahaan tersebut bisa menjadi informasi tambahan yang sangat berharga bagi mahasiswa beliau. Jika kita bandingkan dengan dosen dengan latar belakang akademik murni, jelas tingkatan ilmunya jauh berbeda. Berbagi ilmu inilah yang menjadi sarana aktualisasi beliau dalam menyalurkan ilmu maupun "hobi" yang dimiliki daan menjadi dasar kuat beliau meninggalkan zona nyaman beliau sebagai karyawan BUMN.

\section{KESIMPULAN}

Hasil dari penelitian ini dapat disimpulkan sebagai berikut:

1. Rasa bosan merupakan alasan pertama dari obyek untuk resign dari perusahaan. Karena manajemen memperbolehkan beliau kuliah, maka solusi untuk ini sudah didapatkan.

2. Rasa kecewa terhadap keputusan manajemen sempat menjadikan alasan untuk resign. Namun keloyalitasan beliau untuk perusahaan masih bisa membuatnya bertahan. 
3. Budaya organisasi yang berubah dikarenakan pergantian kepemimpinan, merupakan faktor utama keputusan beliau untuk resign. Beliau merasa sakit hati karena perusahakan melupakan prestasi, keahlian dari seorang karyawan.

4. Keputusan resign juga dipengaruhi dari branding seorang karyawan kepada masyarakat di luar perusahaan. Semakin kuat orang tersebut dikenal, menyebabkan semakin banyak peluang karyawan untuk mandiri.

5. Temuan unik dari kasus ini adalah, obyek adalah orang yang suka berbagi ilmu. Hal ini merupakan salah satu faktor untuk beliau memutuskan resign.

\section{IMPLIKASI PENELITIAN}

Perusahaan harus memberikan kesempatan kepada karyawan untuk mengembangkan diri dengan aturan-aturan yang saling menguntungkan. Budaya organisasi yang telah dirancang sejak awal, sesuai dengan visi misi, selama budaya tersebut baik seharusnya tidak dirubah. Jika memang untuk kepentingan bersama, perubahan seharusnya diterapkan bertahap sehingga tidak menimbulkan kekacauan, kebingungan ataupun keputusan pengunduran diri karyawan.

\section{DAFTAR PUSTAKA}

Becker, F. (1990), The Total Workplace: Facilities Management and the Elastic Organization, Van Nostrand Reinhold, New York, NY.

Choi, J. (2019). Let's agree to disagree? International Journal of Conflict Management. doi:10.1108/ijcma-02-2019-0037

Nina T. Dorata, and Steven T. Petra (2008). CEO duality and compensation in the market for corporate control

Robbins, S. P., \& Timothy. (2015). Perilaku Organisasi. Jakarta: Salemba Empat.

Roethlisberger, F.J. and Dickson, W.J. (1939), Management and the Worker, Harvard University Press, Cambridge, MA.

Sugiyono. (2012). Metode Penelitian Kuantitatif Kualitatif dan R\&D. Bandung: Alfabeta.

Trianasari, Y. (2005). Hubungan Antara Persepsi dan Intensif dan Lingkungan Kerja Dengan kualitas kerja. Surakarta.

Winschel, Julija (2021) Climate change policies and carbon-related CEO compensation systems: an exploratory study of European companie

Zainal, V. R., Ramli, M., Mutis, T., \& Arafah, W. (2014). Manajemen Sumber Daya Manusia Untuk Perusahaan dari teori ke praktek. Jakarta: PT Raja Grafindo Persada. 